\title{
Comparing private security regulation in the European Union
}

\author{
Mark Button and Peter Stiernstedt \\ Institute of Criminal Justice Studies, University of Portsmouth, Portsmouth, UK
}

\begin{abstract}
This paper examines the regulatory systems for the private security industry in the European Union (EU). Building upon other studies to compare regulatory systems it proposes a much more sophisticated approach to assess the quality of regulatory systems using 22 different criteria based on two areas: legislation and societal foundations. From this analysis a maximum of 100 points are possible and the paper is able to rank 26 of the 28 member states of the EU. The league table ranks Belgium and Spain as having the most comprehensive regulatory systems in the EU. The paper then provides analysis of some of the key findings from the league table noting some of the implications. One of the most important of which is the substantial differences between member states and the challenges this poses for an effective single market in the provision of security services.
\end{abstract}

\section{Introduction}

In the European Union (EU) the private security industry has assumed a substantial position in the provision of policing in most Member States (Jones and Newburn 2006, Ocqueteau 2006, Van Steden and Sarre 2007, CoESS 2011). In a number of countries there are statistics, admittedly of varying quality, showing more private security staff employed than public police officers (Republic of Ireland, UK) and in other countries there are substantial private security sectors employing well over 150,000 staff (Germany, Spain and the UK) (Small Arms Survey 2011). These trends are not unique to the EU, with many other areas of the world also experiencing substantial growth in size and role of the private security industry (Shearing and Stenning 1982, Cunningham et al. 1990, Button and Park 2009, Palmer and Button 2011, Small Arms Survey 2011). The involvement in policing, the frequent exercise of legal powers, the use of force - sometimes deadly, along with the particular sensitivities of the security function including (the need to ensure the probity of staff); combined with a variety of problems associated with growing private security industries, such as criminal infiltration, poor standards and excessive use of force, to name some, have all combined to encourage states to introduce special regulatory systems for private security (De Waard and Van De Hoek 1991, De Waard 1993, 1999, Button 2007a, CoESS 2011). The quality of these regulatory systems has varied considerably. In the EU, some countries have been noted as implementing some of the most demanding regulatory systems (Button 2008, Prenzler and Sarre 2008). The systems, however, vary in how exacting they are (De Waard 1993, Button 2007a, 2012, CoESS 2011). These systems are also constantly been reformed and changed.

Juxtaposed to the need for regulation of private security is the increasing integration of the EU and the creation of a single market. The private security industry is treated as a major business services sector and this is despite some attempts by Member States to secure a similar status to state security 
apparatus (CoESS 1998). As such the private security industry would be exempt from these provisions, which the state security apparatus already is. However, such attempts have failed, which means the private security industry is treated like any other business service industry and a private security company or operative legitimately operating in one Member State can do so in another based upon the home country authorisation. As this paper will show, notwithstanding, there are significant differences in standards, not only hampering the notion of a single market but also opening up some interesting opportunities for exploitation for the ruthless.

The purpose of this paper, nevertheless, is not to highlight these opportunities. Rather, it is to compare the regulatory systems of the countries of the EU. Note that it is the regulatory systems that are compared, not the compliance thereof. Comparative research in criminal justice has not been extensive and even less so for private security (Jones and Newburn 2006, Pakes 2004). Such approaches offer many benefits, as Jones and Newburn (2006, p. 2) argue, 'Comparative criminological research is essential in order to better understand similarities and differences within and between jurisdictions, and to gain a deeper understanding of social reality in different national contexts.' Which is an argument for creating a league table like this one as good as any, with an end product open to opinions, criticism and scholarly review. All subsequently leading to anything from a total dismissal of league tables altogether, although unlikely, to the development of a comparative base for European policy-making. Where this research, if nothing else, can act as a starting point for a more nuanced and informed debate, on local, national and supranational level alike, on where to go next with private security regulation in Europe.

One example of such criminological research, adjacent although not perfectly aligned with this approach is the work of Hough et al. (2012) about the police analysed along the dimensions of public trust and perceived legitimacy. The findings are summarised as, trust in the police is an important factor in shaping people's sense of police legitimacy, and trust in police fairness is the crucial dimension across Europe. The model used group countries into the following types: Neoliberal; Conservative corporatist; Social democratic corporatist; Southern European; Post-communist and Israel. The typology introduced could make for an interesting comparison with the findings of this research though not permitted within the confines of this paper. Same goes for another perspective presented by Lacey (2008) in her book 'The prisoners' dilemma: Political economy and punishment in contemporary democracies'. The overarching question posed by Lacey is 'under which conditions are political systems able to combine, in their penal policy, a respect for democratic representation and social inclusion?' The analysis focused on the penal system examine key institutional differences between national systems - an analysis that could be adapted and adopted in a comparative discussion related to this research.

More to the point, there have also been previous attempts to compare regulatory systems in Europe and elsewhere in the world (De Waard and Van De Hoek 1991, De Waard 1993, 1999, Prenzler and Sarre 1999, Hemmens et al. 2001, Button and George 2006, Sarre and Prenzler 2011). There have also been attempts at a league table of the private security industries and regulatory systems (see Button 2007a, Berglund, n.d.), however not to the extent and detail offered in this paper. The scope, however limited, and subsequent content, however flawed, is quite ambitious in comparison to the few previous data collations in a European context. Also generally on the global scene the existence of league tables of this sort are scarce, probably more as a result of the inherent difficulties in data collection in some parts of the world rather than contested usefulness. Thus, in short, this paper seeks to provide a comparison of the regulatory systems of the EU, based on and illustrated by a league table. It also uses a set of criteria that have been developed from the recent work of the United Nations Office on Drugs and Crime, among others, as a foundation to create an ideal framework for the regulation of private security in Europe (UNODC 2014).

The paper will start by examining previous research on the comparison of private security across countries, with a specific focus upon regulation. The paper will then outline the methods used for this research to construct the league table. Next the league table of EU states will be presented, with 
further sub-analysis. The implications of the findings from the league table are then examined, with particular reference to the single market, before offering a conclusion.

\section{European private security, regulation and comparison}

Comparing statistics on police numbers poses a significant challenge because of the different roles they undertake across countries (Stenning 1989). However, statistics on the size of the private security industry pose even greater challenges because they are notoriously variable in their quality and the methodologies vary significantly across countries, not to mention definition differences, high labour turnover rates and a substantial number of part-time employees to name some (Van Steden and Sarre 2007). There has, nevertheless, clearly been a substantial growth in the numbers of private security staff in the countries of the EU (CoESS 2011). The problems with the comparison of statistics relating to private security staff, makes the authors uneasy about offering a European comparison as much of the data on statistics on the size of private security it is difficult to investigate the quality of the methods used. So rather than offer a complete picture of the EU the size of the private security sector, by numbers employed, relative to the police in the five largest EU economies is presented to illustrate some of the wide differences. The largest per capita private security sector is the UK at 527.8 staff per 100,000 , which compares to 78.7 in Italy. However, Italy has a much larger number of police officers. Spain has a large private and public sector, but the public sector is still bigger, with only the UK having a bigger private sector than the public. In France, Germany and Spain the ratio of private security staff to public police officers are all fairly comparable (Table 1 ).

The growth in size of civilian private security has been matched in many Member States by expansion in role. Many of the functions traditionally assumed by the public police are undertaken by private security, such as the patrol of public areas, investigation of crimes, exercising powers such as search and arrest, the provision of armed guarding services, to name some (Jones and Newburn 1998, Hainmuller and Lemnitzer 2003, Gimenez-Salinas 2004, Ocqueteau 2006, Button 2007b, Van Steden 2007, CoESS 2011). The presence of uniformed guards in mass private spaces, such as shopping malls, universities, hospitals, gated communities and entertainment zones, or at the doors of hotels and banks, is now ubiquitous in most EU countries, as is their role in protecting government facilities such as office complexes and critical infrastructure, including transportation hubs and energy facilities (Hainmuller and Lemnitzer 2003, Wakefield 2003, Gimenez-Salinas 2004, Button 2007b, Van Steden 2007, CoESS 2011). As well, private individuals with the means to purchase personal security where public policing services may be weak or seen as ineffective help grow the industry (Davis 1998, Johnston and Shearing 2003, Crawford and Lister 2004).

In the broader field of private policing research, private security regulation has secured significant attention among researchers, although the totality of private policing research is still relatively small compared to public policing research. Research on regulation of private security has tended to encompass cases for regulation (Hakala 2008), the political context to regulation (White 2010), critiques of existing systems or parts of them (Prenzler et al. 1998, Gimenez-Salinas 2004, Button 2011, Cihan 2013, Santonen and Passonen 2014) and comparison of state systems in federal

Table 1. Police and private security staff statistics compared in the five largest economies of the EU.

\begin{tabular}{lcccccc}
\hline Country & Population & $\begin{array}{c}\text { Police } \\
\text { officers }\end{array}$ & $\begin{array}{c}\text { Private } \\
\text { security staff }\end{array}$ & $\begin{array}{c}\text { Police officers } \\
\text { per 100,000 }\end{array}$ & $\begin{array}{c}\text { Private security staff } \\
\text { per 100,000 }\end{array}$ & $\begin{array}{c}\text { Private security staff to } \\
\text { police officer ratio }\end{array}$ \\
\hline France & $65,856,609$ & 203,982 & 147,000 & 309.7 & 223.2 & 0.72 \\
Germany & $80,780,000$ & 243,982 & 168,000 & 302.0 & 208.0 & 0.69 \\
Italy & $60,782,668$ & 276,750 & 47,858 & 455.3 & 78.7 & 0.17 \\
Spain & $46,507,760$ & 249,907 & 188,000 & 537.3 & 404.2 & 0.75 \\
United & $64,308,261$ & 160,566 & 339,440 & 249.7 & 527.8 & 2.11 \\
$\quad$ Kingdom & & & & & & \\
\hline
\end{tabular}


systems or in regions of the world (Cunningham et al. 1990, Prenzler and Sarre 1999, De Waard 1993, Hemmens et al. 2001, Weber 2002). Comparisons have tended to follow basic criteria such as sectors covered by regulation, levels of training, licensing conditions and so on. An exception is the work of Button and George (2006) and Prenzler and Sarre (2008) who have identified models of regulation for private security drawn from cross system comparisons. The former authors have produced models of regulation based upon several criteria. These include the width of regulation, which is the extent of private security industry subject to regulation. Wide systems regulate beyond the manned guarding and private investigatory sectors to cover security consultants, security equipment installers, whereas Narrow focus on manned guarding and or private investigators. The depth of regulation, which is the extent regulations apply to enhance the quality of the private security sector, by setting standards for employees and companies and by setting standards beyond character for owners and employees with training and minimum standards of operation (Button and George 2006). Comprehensive systems set standards of entrance for firms and individuals, with operating conditions for the former and training standards for the latter. Minimal systems by contrast fall short in one or more of these areas. Button and George (2006) also argued systems can be compared by levels of compliance, offering a simple high or low binary classification - but also acknowledging there is a lack of data to offer scholars much to go on for this division. Finally Button and George (2006) noted regulatory systems could be compared on whom has responsibility between monopoly and divided. The former has one body responsible for regulation, which was their preferred option; while the latter has multiple, either based upon territory, that is, different bodies covering different areas of a country or functional, where distinct parts of the private security sector have different regulatory bodies.

From the first two criteria, depth and width, Button and George (2006) offered five models of regulation. Non-interventionist is the first, where the country has no regulation. Then there are Minimum Narrow and Minimum Wide, followed by Comprehensive Narrow and Comprehensive Wide, the final of which is their preferred option. The model has provided a useful means to compare systems and offer a basic insight on how good they are. However, as more regulatory systems have been introduced and reformed, particularly in a European context, many of the systems have moved into the Comprehensive Narrow or Wide models. The only significant difference being picked up by this model is the width of regulation, failing to detect the substantial differences that still exist between systems in how deep they are. To try and offer greater sensitivity to differences Button (2007a) developed the only league table of private security regulatory systems of the then $15 \mathrm{EU}$ Member States. That study only focussed upon the static guarding sector, when in reality the industry and many regulatory systems are much broader than this (this was because of the lack of publicly available data available to do a full analysis at the time). It also only used five criteria, partially linked to the Button and George model.

The aim of this paper is, using the analogy of astronomers, seeking to better understand space is to build a much more sophisticated and sensitive telescope with which to view private security regulatory systems. To do this the paper builds upon the work of Button and George (2006), Prenzler and Sarre (2008) and Button (2007a) by creating a much more sophisticated tool for analysis and league table based upon an examination of the wider regulatory system, but also rooted in the foundations of the key criteria for regulation set out in the UNODC Handbook (2014) State Regulation Concerning the Civilian Private Security Services and their Contribution to Crime Prevention and Community Safety and other appropriate guides. The way the handbook is written made the task of turning the criteria into points an onerous one. Nevertheless, through a process of independent assessment, debate and reflection the authors arrived at the points system that will shortly be discussed. The authors do not see the criteria and points as the final destination of the research, rather as the first attempt, which hopefully will stimulate further debate and reflection as well as suggestions for reform.

Such debate could stem from traditional considerations on regulation as presented by Loader (1997) centred around the normative aspects of locating private security within some kind of framework of democratic deliberation and decision-making. Given that private security does not sort well as any market controlled commodity there is certainly scope for comparative analysis across the EU 
on the connection between the provision of security and political authority. The analysis can also be extended to further typologies such as that presented by Smith and White (2014) who by adding a layer of complexity end up with the following three regulatory objectives: public protection, regulatory capture and normative legitimation. Regulatory legitimacy is often discussed from the perspective of substantive and procedural legitimacy, but seldom normative legitimacy. In the neoliberal setting present in many EU Member States there is contention such that it potentially give rise to a paradoxical relationship between public protection and normative legitimation. This rather counterintuitive notion could also serve as basis for expansion of the league table both in terms of its rational foundation as well as its content.

This will gradually create a set of criteria and points for analysis which will gain wide acceptance across the EU and possibly even broader. The end point is to create a transferable structure with wide acceptance, the authors accept there will be critique of their approach but are prepared to 'put their heads above the parapet' to start the debate. Ultimately the authors are committed to effective regulation, as the means to enhance the important contribution of private security to crime prevention and community safety and believe this paper will contribute to the body of knowledge to help states achieve this. Regulation is seen as essential to achieving this, although this does not mean that all regulation is good. Regulation must be tailored to enhancing private security and not hindering or smothering it, which can occur. The authors' perspective throughout is therefore that tailored regulation is good, providing the normative basis for an effective private security industry operating to high standards contributing to crime prevention and community safety. Conversely bad or no regulation undermines standards and the contribution to crime prevention and community safety. In that context this paper is important in drawing out some of the normative aspects of private security regulation.

\section{Methodology}

The purpose of the league table is to illustrate the current state of private security regulation in the Member States of the EU. This is realised by identifying a number of questions pertinent to the issue, ascribing these questions a relative weight, assigning an individual value and by adding up these values creating a league table. The questions were determined by first synthesising the inquisitive paradigms of the following four resources. Firstly, the 2014 UN Handbook on state regulation concerning civilian private security services (UNODC 2014). The Handbook provides a broad outline and analysis of essential regulatory requirements for private security services. Secondly, the Private Security Services in Europe - Confederation of European Security Services (CoESS) Facts \& Figures (CoESS 2011) providing a comprehensive overview of the European private security services landscape. Thirdly, the ECORYS report on security regulation, conformity assessment and certification produced for the European Commission (ECORYS 2011). This report describes the findings from a study on security regulation, conformity assessment and certification The fourth resource was the article by Button (2007a), which in and by itself is based on the three studies of private security regulation by the CoESS and Union Network International Europe (Weber 2002, CoESS/UNI-Europa 2004, CoESS 2004), accompanied by the latest edition of the CoESS facts and figures for private security services in Europe (CoESS 2011). In addition to these reports several other sources were subsequently used. These sources include various other European studies, academic research articles and reports, government websites and interviews with industry professionals, all of which are cited where used.

What arose from the synthesis of the three first resources was not only the emergence of a conceptual framework outlining the fundamentals of private security regulation in the EU, but also a number of contextual requirements essential to the stability of the framework. It was these requirements that were translated into the questions pertaining to the legislative side of private security. Also of importance as a counter balance to and product of the legislation, is the societal foundation, the actual implementation of legislation into the private security industry. Not exactly equally balanced as the latter is largely the product of the former this made up the fundamental structure 


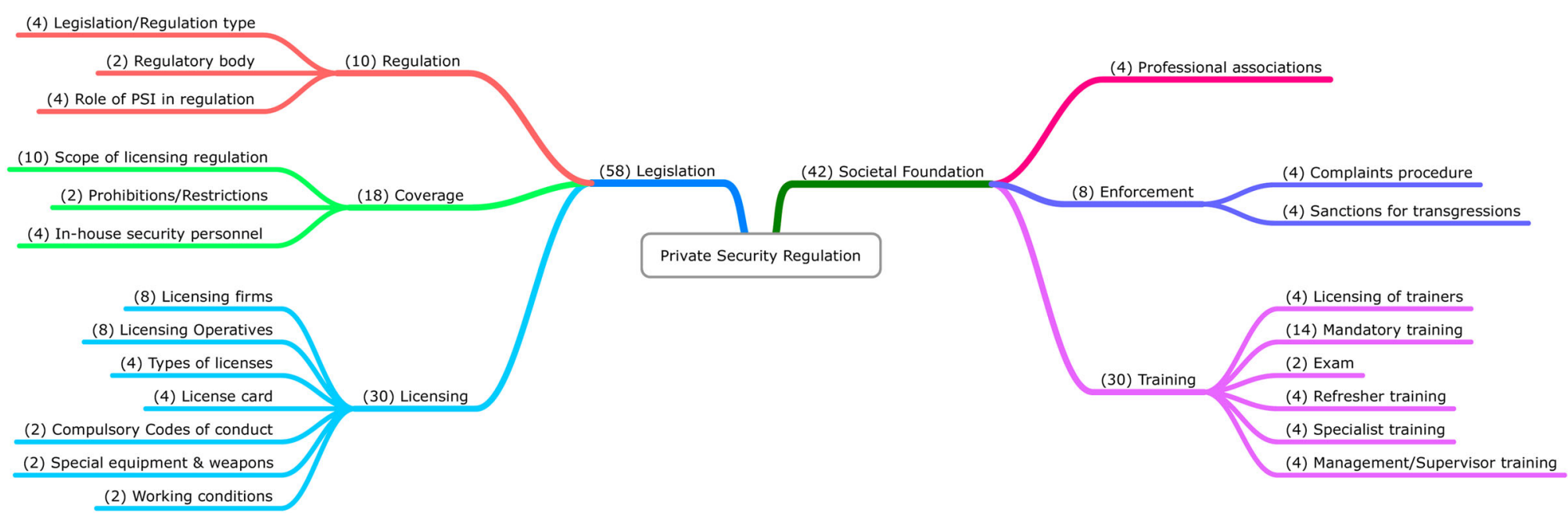

Figure 1. The sub-divisions and questions of the league table. 
Table 2. Overall score six top and bottom performers, plus the EU founding countries.

\begin{tabular}{llllll}
\hline Top performers & Score & Bottom performers & Score & EU founding countries & Score \\
\hline Belgium & 94 & Slovakia & 50 & Belgium & 94 \\
Spain & 88 & Italy & 46 & Luxembourg & 68 \\
Slovenia & 82 & Cyprus & 42 & Germany & 66 \\
Greece & 80 & Lithuania & 42 & France & 64 \\
Sweden & 78 & Austria & 40 & Netherlands & 62 \\
Portugal & 78 & Czech Republic & 22 & Italy & 46 \\
\hline
\end{tabular}

for the calculations to come. Thus the definition of these two main divisions can loosely be defined as; legislation, those aspects pertaining directly or indirectly to the actual national legislative framework, and the societal foundation as the direct or indirect consequences of that legislation upon its implementation into the society.

The formulation of the questions, the weight of each question, that is, the maximum value, as well as the various partitions of points within an individual question was determined by a method resembling constant comparison (Glaser and Strauss 1967, Pidgeon and Henwood 1997). For this research this meant formulating initial questions from the first data analysed and then allowing those questions to evolve as further data was analysed. This method was applied also when assigning weight and values to the questions, constantly refining and balancing the array of questions in the league table. The method, although changing the nature of the questions as the research progressed, allowed the analysis to reach a higher level of abstraction - drawing out, adjusting for and integrating integral and pertinent aspects making the entire league table be far greater than the sum of its parts. The final set of questions, their weight and the balance between the technical aspects of the rather theoretical legislation with the pragmatically oriented practical effects thereof is illustrated by Figure 1.

Before embarking on this analysis, however, it is important to note some caveats. Regulations are constantly changing and consequently many of the sources consulted are soon out of date. Thus, exploring different systems of regulation can be viewed at best as a snapshot in time. Second, the data presented in some studies do not always match others and this may reflect use of dated sources, a genuine mistake by an author or differences in interpretation of legal regulations. Another important aspect intentionally omitted from this work is the level of compliance to the various regulatory systems. The research has been focused on comparing the theoretical foundation as laid out by the legislation in each Member State, with the practical implementation of the same may be the focus for another study. Bearing these caveats in mind, however, all efforts have been made to verify the data used for this paper so that it represents as accurate a snapshot of regulation as is possible at the time of writing. ${ }^{1}$

In answering the questions that emerged a three-pronged approach was applied. Firstly, extant literature on the subject was reviewed. Centring on the same resources that were used for the creation of the questions, several answers were found in these or related writings. The second step, since most national legislation is publicly available, was a desktop-based process in which official documents were reviewed. This further filled the gaps and also provided some of the countries with more updated information. Still having some areas unanswered the third and last step comprised the use of the authors' networks. Establishing direct or indirect contacts, the latter as a result of snowballing, the final gaps were filled. Leaving all but two countries (Croatia and Hungary), readily available for further analysis.

\section{The league table}

Two countries were excluded from the league table due to insufficient data and another two contain minor gaps that allow them to still remain in the analysis. Excluded countries are Croatia and Hungary; the countries with minor gaps are Latvia and Slovakia. Hence a total of 26 of the 28 EU 
Table 3. The league table showing criteria and score for 26 EU Member states (1).

\begin{tabular}{|c|c|c|c|c|c|c|c|c|c|c|c|c|c|c|c|c|}
\hline $\begin{array}{l}\text { EU member } \\
\text { state }\end{array}$ & $\begin{array}{l}\text { Year } \\
\text { of } \\
\text { entry }\end{array}$ & $\begin{array}{l}\text { Legislation/ } \\
\text { regulation } \\
\text { type }\end{array}$ & $\begin{array}{l}\text { Single } \\
\text { regulatory } \\
\text { body }\end{array}$ & $\begin{array}{l}\text { Role of PSI } \\
\text { in } \\
\text { regulation }\end{array}$ & Regulation & $\begin{array}{l}\text { Scope of } \\
\text { licensing } \\
\text { regulation }\end{array}$ & $\begin{array}{c}\text { Prohibitions/ } \\
\text { restrictions }\end{array}$ & $\begin{array}{c}\text { In-house } \\
\text { security } \\
\text { personnel }\end{array}$ & Coverage & $\begin{array}{l}\text { Licensing } \\
\text { firms }\end{array}$ & $\begin{array}{l}\text { Licensing } \\
\text { operatives }\end{array}$ & $\begin{array}{l}\text { Types of } \\
\text { licenses }\end{array}$ & $\begin{array}{l}\text { License } \\
\text { card }\end{array}$ & $\begin{array}{c}\text { Compulsory } \\
\text { codes of } \\
\text { conduct }\end{array}$ & $\begin{array}{c}\text { Special } \\
\text { equipment } \\
\text { and weapons }\end{array}$ & $\begin{array}{c}\text { Working } \\
\text { conditions }\end{array}$ \\
\hline & & 4 & 2 & 4 & 10 & 10 & 2 & 4 & 16 & 8 & 8 & 4 & 4 & 2 & 2 & 2 \\
\hline Belgium & 1952 & 4 & 2 & 4 & 10 & 10 & 2 & 4 & 16 & 8 & 8 & 4 & 4 & 0 & 2 & 2 \\
\hline Spain & 1986 & 4 & 2 & 0 & 6 & 12 & 2 & 4 & 18 & 8 & 8 & 4 & 4 & 0 & 2 & 2 \\
\hline Slovenia & 2004 & 4 & 2 & 4 & 10 & 10 & 0 & 4 & 14 & 4 & 8 & 4 & 4 & 2 & 0 & 0 \\
\hline Greece & 1981 & 4 & 2 & 2 & 8 & 10 & 0 & 4 & 14 & 8 & 4 & 0 & 4 & 2 & 2 & 2 \\
\hline Sweden & 1995 & 4 & 0 & 2 & 6 & 10 & 2 & 0 & 12 & 4 & 4 & 4 & 4 & 0 & 2 & 2 \\
\hline Portugal & 1986 & 4 & 2 & 2 & 8 & 10 & 0 & 4 & 14 & 8 & 4 & 4 & 4 & 0 & 2 & 2 \\
\hline Ireland & 1973 & 4 & 2 & 4 & 10 & 10 & 0 & 4 & 14 & 4 & 8 & 4 & 4 & 2 & 2 & 2 \\
\hline Finland & 1995 & 4 & 2 & 4 & 10 & 8 & 0 & 0 & 8 & 8 & 8 & 3 & 4 & 0 & 2 & 2 \\
\hline Romania & 2007 & 0 & 0 & 4 & 4 & 10 & 0 & 4 & 14 & 4 & 8 & 0 & 4 & 0 & 2 & 0 \\
\hline Luxembourg & 1952 & 4 & 2 & 4 & 10 & 8 & 2 & 0 & 10 & 4 & 4 & 0 & 4 & 0 & 2 & 2 \\
\hline Germany & 1952 & 4 & 2 & 2 & 8 & 6 & 0 & 0 & 6 & 8 & 4 & 2 & 4 & 2 & 2 & 2 \\
\hline Malta & 2004 & 4 & 2 & 2 & 8 & 4 & 0 & 4 & 8 & 8 & 8 & 2 & 4 & 0 & 0 & 2 \\
\hline France & 1952 & 4 & 2 & 4 & 10 & 8 & 2 & 4 & 14 & 4 & 8 & 0 & 4 & 2 & 2 & 2 \\
\hline Netherlands & 1952 & 4 & 2 & 0 & 6 & 10 & 0 & 0 & 10 & 4 & 8 & 0 & 4 & 0 & 0 & 2 \\
\hline Estonia & 2004 & 4 & 2 & 0 & 6 & 6 & 0 & 4 & 10 & 4 & 8 & 0 & 4 & 0 & 2 & 2 \\
\hline Poland & 2004 & 0 & 2 & 0 & 2 & 4 & 0 & 4 & 8 & 8 & 4 & 0 & 4 & 0 & 2 & 2 \\
\hline Denmark & 1973 & 4 & 2 & 4 & 10 & 4 & 0 & 0 & 4 & 4 & 8 & 0 & 4 & 0 & 2 & 0 \\
\hline Latvia & 2004 & 4 & 0 & 0 & 4 & 4 & 0 & 4 & 8 & 8 & 4 & 0 & 4 & 0 & 0 & 0 \\
\hline Bulgaria & 2007 & 4 & 2 & 4 & 10 & 4 & 0 & 4 & 8 & 4 & 0 & 0 & 4 & 0 & 2 & 0 \\
\hline $\begin{array}{l}\text { United } \\
\text { Kingdom }\end{array}$ & 1973 & 4 & 2 & 4 & 10 & 10 & 0 & 0 & 10 & 0 & 8 & 4 & 4 & 0 & 0 & 0 \\
\hline Slovakia & 2004 & 4 & 2 & 4 & 10 & 6 & 0 & & 6 & 0 & 0 & 0 & 4 & 0 & 2 & 0 \\
\hline Italy & 1952 & 2 & 2 & 0 & 4 & 8 & 0 & 4 & 12 & 4 & 4 & 0 & 4 & 0 & 2 & 2 \\
\hline Cyprus & 2004 & 4 & 2 & 0 & 6 & 10 & 0 & 4 & 14 & 4 & 8 & 0 & 4 & 0 & 0 & 2 \\
\hline Lithuania & 2004 & 0 & 2 & 0 & 2 & 6 & 2 & 0 & 8 & 4 & 8 & 0 & 4 & 0 & 0 & 0 \\
\hline Austria & 1995 & 0 & 0 & 0 & 0 & 8 & 0 & 0 & 8 & 4 & 8 & 2 & 0 & 0 & 2 & 2 \\
\hline $\begin{array}{l}\text { Czech } \\
\text { Republic }\end{array}$ & 2004 & 0 & 2 & 0 & 2 & 0 & 0 & 0 & 0 & 4 & 4 & 0 & 4 & 0 & 2 & 0 \\
\hline
\end{tabular}


Table 3. Continued.

\begin{tabular}{|c|c|c|c|c|c|c|c|c|c|c|c|c|c|c|c|c|}
\hline $\begin{array}{l}\text { EU member } \\
\text { state }\end{array}$ & Licensing & $\begin{array}{l}\text { Subtotal - } \\
\text { legislation }\end{array}$ & $\begin{array}{l}\text { Professional } \\
\text { associations }\end{array}$ & $\begin{array}{l}\text { Professional } \\
\text { associations }\end{array}$ & $\begin{array}{c}\text { Complaints } \\
\text { procedure }\end{array}$ & $\begin{array}{c}\text { Sanctions for } \\
\text { transgressions }\end{array}$ & Enforcement & $\begin{array}{l}\text { Licensing } \\
\text { of trainers }\end{array}$ & $\begin{array}{l}\text { Mandatory } \\
\text { training }\end{array}$ & Exam & $\begin{array}{c}\text { Refresher } \\
\text { training }\end{array}$ & $\begin{array}{c}\text { Specialist } \\
\text { training }\end{array}$ & $\begin{array}{l}\text { Management/ } \\
\text { supervisor } \\
\text { training }\end{array}$ & Training & $\begin{array}{c}\text { Subtotal - } \\
\text { social } \\
\text { foundation }\end{array}$ & Total \\
\hline & 30 & 56 & 4 & 4 & 4 & 4 & 8 & 4 & 14 & 2 & 4 & 4 & 4 & 32 & 44 & 100 \\
\hline Belgium & 28 & 54 & 4 & 4 & 0 & 4 & 4 & 4 & 14 & 2 & 4 & 4 & 4 & 32 & 40 & 94 \\
\hline Spain & 28 & 52 & 4 & 4 & 0 & 4 & 4 & 4 & 14 & 2 & 4 & 4 & 4 & 32 & 40 & 92 \\
\hline Slovenia & 22 & 46 & 4 & 4 & 0 & 4 & 4 & 4 & 10 & 2 & 4 & 4 & 4 & 28 & 36 & 82 \\
\hline Greece & 22 & 44 & 4 & 4 & 0 & 4 & 4 & 4 & 14 & 2 & 4 & 0 & 4 & 28 & 36 & 80 \\
\hline Sweden & 20 & 38 & 4 & 4 & 0 & 4 & 4 & 4 & 14 & 2 & 4 & 4 & 4 & 32 & 40 & 78 \\
\hline Portugal & 24 & 46 & 4 & 4 & 0 & 4 & 4 & 4 & 6 & 2 & 4 & 4 & 4 & 24 & 32 & 78 \\
\hline Ireland & 26 & 50 & 4 & 4 & 4 & 4 & 8 & 4 & 4 & 0 & 0 & 4 & 0 & 12 & 24 & 74 \\
\hline Finland & 27 & 45 & 4 & 4 & 0 & 2 & 2 & 4 & 12 & 2 & 0 & 0 & 0 & 18 & 24 & 69 \\
\hline Romania & 18 & 36 & 4 & 4 & 0 & 4 & 4 & 4 & 14 & 2 & 0 & 4 & 0 & 24 & 32 & 68 \\
\hline Luxembourg & 16 & 36 & 4 & 4 & 0 & 4 & 4 & 4 & 10 & 2 & 4 & 4 & 0 & 24 & 32 & 68 \\
\hline Germany & 24 & 38 & 4 & 4 & 0 & 4 & 4 & 4 & 6 & 2 & 0 & 4 & 4 & 20 & 28 & 66 \\
\hline Malta & 24 & 40 & 4 & 4 & 0 & 4 & 4 & 4 & 3 & 2 & 4 & 4 & 0 & 17 & 25 & 65 \\
\hline France & 22 & 46 & 4 & 4 & 0 & 4 & 4 & 0 & 8 & 2 & 0 & 0 & 0 & 10 & 18 & 64 \\
\hline Netherlands & 18 & 34 & 4 & 4 & 0 & 4 & 4 & 4 & 14 & 2 & 0 & 0 & 0 & 20 & 28 & 62 \\
\hline Estonia & 20 & 36 & 4 & 4 & 0 & 4 & 4 & 4 & 8 & 2 & 0 & 0 & 4 & 18 & 26 & 62 \\
\hline Poland & 20 & 30 & 4 & 4 & 0 & 4 & 4 & 0 & 14 & 0 & 4 & 0 & 4 & 22 & 30 & 60 \\
\hline Denmark & 18 & 32 & 4 & 4 & 0 & 4 & 4 & 4 & 12 & 2 & 0 & 0 & 0 & 18 & 26 & 58 \\
\hline Latvia & 16 & 28 & 4 & 4 & 0 & 4 & 4 & 4 & 14 & 2 & 0 & 0 & 0 & 20 & 28 & 56 \\
\hline Bulgaria & 10 & 28 & 4 & 4 & 0 & 4 & 4 & 4 & 6 & 2 & 0 & 4 & 4 & 20 & 28 & 56 \\
\hline $\begin{array}{l}\text { United } \\
\text { Kingdom }\end{array}$ & 16 & 36 & 4 & 4 & 0 & 2 & 2 & 0 & 6 & 2 & 0 & 4 & 0 & 12 & 18 & 54 \\
\hline Slovakia & 6 & 22 & 4 & 4 & 4 & 4 & 8 & 4 & 6 & 2 & 0 & 0 & 4 & 16 & 28 & 50 \\
\hline Italy & 16 & 32 & 4 & 4 & 0 & 4 & 4 & 4 & 0 & 2 & 0 & 0 & 0 & 6 & 14 & 46 \\
\hline Cyprus & 18 & 38 & 0 & 0 & 0 & 4 & 4 & 0 & 0 & 0 & 0 & 0 & 0 & 0 & 4 & 42 \\
\hline Lithuania & 16 & 26 & 4 & 4 & 0 & 0 & 0 & 4 & 6 & 2 & 0 & 0 & 0 & 12 & 16 & 42 \\
\hline Austria & 18 & 26 & 4 & 4 & 0 & 4 & 4 & 4 & 2 & 0 & 0 & 0 & 0 & 6 & 14 & 40 \\
\hline Czech & 14 & 16 & 4 & 4 & 0 & 2 & 2 & 0 & 0 & 0 & 0 & 0 & 0 & 0 & 6 & 22 \\
\hline
\end{tabular}

Republic 
Member States are included and analysed in the league table. The first level of analysis is naturally to look at the total score achieved by each individual Member State. With the top performers being Belgium with an overall score of 94 out of a maximum 100, followed by Spain with 88 and then Slovenia with 82. On the other side of the spectrum the two countries Cyprus and Lithuania, share third place from the bottom with 42. Austria is second to last with 40 and last by some degree is the Czech Republic with 22. As reference countries Sweden takes fifth place with 78 and the UK comes in eighteenth with 54. Table 2, an excerpt presenting the six overall score top and bottom performers together with the founding countries of the EU.

The average total scorei $\mu$, for the 26 Member States is 64 - the exact score of only France but coincidentally also the average of the five largest economies of the EU discussed earlier. As other interesting comparisons the Scandinavian average (Denmark, Finland, Sweden) is 68 and the Mediterranean average (Cyprus, France, Greece, Italy, Malta, Slovenia, Spain) is 67. With several averaged total scores ending up in the same region as the total average the next question beckoning is that of the variance. Treating the 26 countries as the entire population, which is true at least for the confines of the analysis, the uncorrected standard deviation, $\sigma$ is 16 . Assuming a normal distribution the countries outside the normal distribution of the first band $(\mu \pm 1 \sigma)$ from 48 to 80 can be identified. Above are Belgium (94), Spain (92) and Slovenia (82), the countries on the lower side are Italy (46), Cyprus (42), Lithuania (42) Austria (40) and the Czech Republic (22). The second band $(\mu \pm 1 \sigma)$ from 31 to 97 singles out the Czech Republic falling below the lower delimiter on what can only be considered an alarmingly low total score. The league table can be found in its entirety in Table 3.

The overall score provides an indication of the quality of the regulatory system in each Member State, nonetheless it is in essence just an expanded more detailed version of the same sort of analysis provided by Button (2007a). This increased level of detail is evident when for instance looking at Belgium getting a perfect score of 100 in the original study and in the current table losing a total of six points due to the lack of a compulsory code of conduct and a formalised complaints procedure. Having said that, only five countries have a compulsory code of conduct and only two have a formalised complaints procedure. Though it should be noted that the more advanced methodology applied for this league table in many respects yield the same result as the table by Button in 2007. For the fifteen countries then analysed, the two countries given a full score in 2007 are the same countries that are first and second in this league table. Conversely the table from 2007 placed UK and Italy among the bottom three which corresponds to the current league table.

The sub-divisions shown earlier do, however, lend this league table to further and deeper analysis. As an example one can look at the top performers of the main division, legislation on one hand and societal foundation on the other. To no surprise Belgium comes in first in both categories, but in second place for legislation Spain has to give way to Ireland. For societal foundation the three countries of Belgium, Sweden and Spain all share first place. This type of sub-division analysis can be extended to the groupings of questions, that is, regulation, coverage and licensing, all under the heading of legislation as well as professional associations, enforcement and training which pertains to societal foundation. For example, when looking at coverage, comprising of the scope of regulation, the prohibitions and restrictions therein as well as whether or not in-house security personnel are included in regulation, Belgium is the only country with a faultless score. That indicates that almost all of the EU Member States have regulation which does not completely cover the principal activities of the private security industry, which would be expected to be included.

In an attempt to find the main issues pertaining to comprehensive regulation an in-depth analysis of the various sub-divisions going all the way down to individual questions was performed. The analysis, fundamentally built upon questions intentionally designed to be blunt allowing for easy and fair assignment of discrete values, delivered equally blunt answers. In this case blunt is not necessarily bad, but rather it quite clearly highlights three key issues that an effective regulation for private security must address. Those key issues are, the inclusion and emphasis of quality enhancing standards, 
recognising and addressing the complexity of private security and to have a wide yet sufficiently specific range of regulation.

If firstly looking at the inclusion and emphasis of quality enhancing standard the findings of this study concur with the observations in the UN Handbook (UNODC 2014) that regulated standards and norms allow private security to make a more effective contribution to society, which builds upon a body of research (see e.g. De Waard 1999, Button and George 2006, Button 2007a, Hakala 2008, Prenzler and Sarre 2008). A contribution including the enhancement of human rights, fighting crime and upholding criminal justice. To exemplify, the case of an appropriate amount of mandatory training addresses not only the proficiency and efficacy of security personnel, but would also negate many of the identified weaknesses of the industry. Such weaknesses can be the abuse of authority, excessive use of force, low professional standards, and non-compliance with the law. The minimum training stipulated by this research is 120 hours for an unarmed guard, a figure developed by using the CoESS European Training Manual for a Security as the basis (European Private Security Services Education and Training 1999). Yet there are only seven countries that mandate this or more in the EU: Romania (360 hours), Hungary (320 hours), Sweden (288 hours), Poland (245), Spain (180 hours), Latvia (160 hours) and Belgium (127 hours) (in the Greece and Netherlands there are mandatory diplomas rather than hours). The rest fall below this, with a handful mandating no or little more than a few days training (Austria, Cyprus, Czech Republic, Ireland, Malta, Poland, UK). Although beyond the scope of this paper, particularly considering the limited amount of words available, these findings do lead to other interesting questions; such as how this is derived from the respective national legislative framework, and the specific context therein. It is of course also important to note that just because there are standards, this does not mean that all companies will follow them and that even those that do, that they will have the desired impact. There is much evidence of non-compliance and one only has to look at extensive standards leading to increased training for police officers in interviewing in England and Wales, but still extensive problems with standards regularly exposed (Milne and Bull 1999, Button 2012). Nevertheless some standards are clearly better than none.

The second point is to recognise and address the complexity of private security pertains not only to the design but also the implementation of a regulatory system enhancing the contribution of private security to crime prevention and community safety. Because even once the decision is taken to regulate, regardless if it is on a nation state level or supranational level, an informed decision must be taken about how it is to be implemented. This is a complex issue that will determine the strength of the regulation, the level of detail, if it should be implemented as new general legislation or as secondary legislation amending the existing. The position taken by the authors based upon conclusions drawn from this study is that at this point private security regulation needs to be addressed by the EU creating a harmonised least level of regulation and conformity. This notion will be further explained shortly.

The third and last point of having a wide yet specific range of regulations stem partly from the fact that the growth of the private security in sheer size is matched only by the expansion of its role. Private security companies now undertake many of the functions traditionally assumed by the public police. An effective regulatory system has to be sufficiently wide to encompass even the very fringes of this ever-expanding role, while at the same time provide such depth and detail to address sensitive areas. Such areas include, but are not limited to, data protection, ethics and integrity, as well as enacting authority and using force. This is a significant challenge with a solution that has to incorporate the institutional cornerstones of the EU, such as the notion of the single market, social and judicial equality as well as the ambition to secure the citizens of Europe. Further, effective EU legislation must also contain an extensive feasibility analysis where the cultural and geopolitical aspects of the Member States are addressed. In the context of regulating private security this is an area in much need of further research.

So where does this analysis leave us? Firstly, taking the analysis before and during the creation of the league table together with the post product analysis, it all clearly points towards not only the necessity of private security regulation in general but even more so on a supranational level in a European context. Secondly, while evidently showing the direction where private security regulation 
needs to be headed the analysis also identifies several areas surrounding this particular path with issues and questions left unanswered. Before divulging into a thought provoking discussion about this, lets delineate the rational for the necessity of a European legislative framework for private security while at the same time highlighting some of the challenges to achieving this.

\section{Implications of the league table}

There are several implications of the conclusions drawn from analysing the league table each equally pertinent in its own right within its own context. Nonetheless there are also implications that are wider in nature, representing the broad brush strokes that would colour the future bright. Externally such broader strokes include EU Security Sector Reform undertakings, spanning both institutional and operational activities. The experience from these reformatory efforts has highlighted the need for improved coordination among instruments as well as between instruments and political goals (Gross 2013). For an internal application one such instrument is the regulation of private security. While coordination undoubtedly contributes to the effectiveness of any actual or proposed regulation, such coordination should rest upon common operational guidance and understanding that underpins the application of the regulation. This is particularly important since private security regulation currently reside within the legislation of the individual Member States with different institutional and organisational cultures. With the continued emphasis on the coherence between EU instruments and regulation perhaps it is time for the subsidiarity principle to step aside for a better, fairer and more secure Europe?

If and when it does a rocky road of developing a supranational directive that could secure a broad level of acceptance across the entire spectrum of civil society within the EU lies ahead. To facilitate compliance further comparative research would be advisable and an analysis of how the Member States would lend themselves to transposition of a private security directive is one suggestion. Falkner (2007) presents a useful typology to this end suggesting three worlds of compliance: a 'world of law observance', a 'world of domestic politics' and a 'world of transposition neglect'. Comparing and sorting the Member States of the EU from the specific perspective and challenges of private security it could shed some light on when and how individual theoretical propositions are relevant.

Obviously this is a much larger discussion and what is presented below can only be considered to scrape the surface. Nontheless, there are at least two angles that deserve to be mentioned, if nothing else to stimulate the debate and further research. These are, firstly the perspective from a European Single market, and secondly in the context of harmonised regulatory fitness.

The European Single Market, allows people and businesses to move and trade freely across borders within the EU, has transformed the way Europeans live, work, travel, do business and study. It has opened up opportunities for businesses to expand successfully not only on the European but by extension also on the global market. Over the years, a number of changes have made this possible. Trade barriers and physical customs controls have been abolished - if still demanded or required provided by private actors. National rules that prevented companies from trading across borders have been harmonised - with such trades secured primarily by private actors. Public procurement rules have been changed so companies can bid on contracts anywhere in the EU - also for private security calling for equal yet somehow unregulated opportunities. In the early years of the single market, now turning 20, the free circulation of services was less developed than that of goods. With services being one of the most dynamic sectors of the European economies, many barriers also in the service sector has been lifted. This allows for companies to offer services in another Member State without prior authorisation from the EU or a particular license other than what required in the country in which the company resides. The differences in private security regulation as demonstrated by the league table do not align well with the ambitions of a functioning and fair single market. In a market driven by price the widely different standards opens up the opportunities for the ruthless to use the lowest standards to drive down overall standards, something familiar in low or non-regulating states (House of Commons Home Affairs Committee 1995, Goold et al. 2010). 
Fairness also extends beyond the immediate business setting in many ways encompassing the entire society of which security is an important part (Johnston and Shearing 2003, Button 2008). Socio-inequalities are on the rise almost everywhere in the world, including Europe and while research convincingly shows that egalitarian societies are associated with higher levels of economic growth (Perrons and Plomien 2010) actual progress to reach those levels are slow. By contrast unequal societies experience higher rates of crime, ill-health drug abuse, and persistent poverty (Wilkinson and Pickett 2009) - factors not irrelevant to the continued growth and importance of the private security sector. EU policies for combatting social inequalities involve directives, regulations or decisions often referred to as 'hard law' instruments; but also include 'soft law' measures that provide a framework and funding for national strategy development and policy coordination between Member States. In light of the findings of this research, whether through soft or hard law, there is an imminent call for coordination and harmonisation. The beneficial societal effects of regulating the private security industry would not necessarily stop with levelling social rifts but through its intrinsic nature would also benefit to the security and safety of Europe's citizens.

One of the priorities of the Stockholm program set out in 2009 is protecting the citizens of Europe. The program, which defines the strategic guidelines for legislative and operational planning within the area of freedom, security and justice, came to an end in 2014. A study commissioned by the European Parliament (2013) on its successor shows a current imbalance between harmonisation and operationalisation due to regulatory gaps. On a grand scale the EU has developed many instruments that touch upon the realm of private security and others are still in the process of being negotiated. This to the extent that the European Policy Centre in a document to support the Justice and Home Affairs Ministers (2013) stressed the need to properly implement the enormous amount of already existing legislation versus the need to adopt new rules in order to fulfil already defined objectives. Needless to say the league table confirms that the regulatory gaps persists and with the increasing size, role and importance of private security any lapse in developing and implementing cohesive legislation may jeopardise the adequate protection of Europe's citizens. In this era of globalisation, where barriers of movement of goods, services and people are diminishing, the citizens of Europe expect their governments to ensure their safety. Whether achieved through national or supranational legislation is of less concern, but vis-à-vis the varied regulation as illustrated by the league table meeting the challenge on a national level may be an insurmountable task. The European Commission recently launched the Regulatory Fitness and Performance Programme (COM 2012), it will combine various initiatives underway aimed at eliminating unnecessary regulatory cost and ensuring that the body of EU legislation remains fit for purpose. Perhaps the initiative as the authors will take issue with the lack of regulating an area where the EU can make a real difference.

\section{Conclusion}

This paper has presented a new more sophisticated tool for analysing systems for the regulation of the private security sector. We did examine other research tangent to this research and there are certainly grounds for further development along those lines although not permitted in this paper. There are limitations to this approach, not least the constantly changing regulatory systems and absence of consideration of levels of compliance, which to be assessed effectively would require a resource intensive large cross-EU research project. The authors do not expect the criteria used for assessing systems to be the final version, but rather the foundations for a tool that will be refined as the debate over effective regulation of private security continues. The analysis has been applied to 26 of the member states, which produced Belgium at the top with 94 points and the Czech Republic at the bottom with 22 points. The average total score is 64 and the standard deviation 16. Perhaps most significant to the scores and allocation of points is the significant difference between Member States as well as the large variance. This, the authors argue raises significant challenges to a EU effective single market in the provision of security services in the EU. In addition it Exposes the weaknesses in the potential of some States - given the importance of regulation in 
the promotion of standards of security - to develop minimum standards of security for citizens and address security inequity. Like so many other areas in policing more research and debate is required on this subject and the authors hope this paper provides the spark for much more attention to this comparatively neglected area. One of the first priorities of the authors will be to reflect further on the implications for EU policy reform and develop a more focussed set of ideas on the best way forward for the EU on the regulation of private security.

\section{Note}

1. 1. For the results of this research to potentially be replicated, critiqued and enhanced what follows is an explanation of the allocation of points in relation to the answers of the 22 questions. The decision to let the total sum of points for all questions be 100 was taken arbitrarily. It is considered a suitable level of detail given the total number of questions and them intentionally being formulated to yield discrete answers. There is nothing that indicates that a scale with a range of 1000 would have given fundamentally different results but would undoubtedly result in a more time consuming process when allocating the points. Particularly since the many of the various intra-question levels are determined qualitatively and each would arguably require being ten times as precise both in accuracy and justification. Hence, in both pragmatic and conceptual terms the scale to 100 was as easily managed, as it is intrinsically easy to understand and relate to.

Firstly there is a main division of questions in two large groups, legislation representing 58 of the total points on one hand and societal foundation representing 42 points on the other. The points given for each of these divisions was a result of the points allocated to the questions within them and not the other way. Ergo, having created the main divisions each division were then subsequently divided into sub-divisions and those in turn consists of individual questions. Allocating points to the questions gave a total score for the sub-divisions that when added up produced the total for each main division. The near 50-50 balance was therefore not intentional, strived for or even necessary yet still quite welcome as this also adds to the conceptual accessibility of the matrix.

Each sub-division consists of a number of individual questions that are presented here in a slightly simplified format. The bracketed number following either a sub-division or an individual questions indicate the sum of maximum points for that sub-division and question, respectively. Each individual question is followed by a breakdown of the answers within that question including allocated points associated with each particular answer. The main divisions are legislation and societal foundation. Beginning with the main division legislation, the three subdivisions are regulation (10), coverage (18) and licensing (30).

Regulation consists of the following three questions (R1-3):

R1. Legislation/Regulation type (4). Where regulation specific to private security gave (4), general legislation with specific amendments addressing private security issues (2) and general legislation (0).

R2. Single regulatory body (2). If a single regulatory body was effectively responsible for all or most private security concerns (2) and if the responsibility was divided or diffuse (0).

R3. Role of PSI in regulation (4). If formally and democratically established and run (4), if informal but influential (2), if having a dominating role, formal or informal (0), and if not holding a significant role in regulation (0).

Coverage consists of the following three questions (C1-3):

C1. Scope of licensing regulation (10). Up to (10) for scope going beyond general standards with (2) for each area. This refers to regulated areas falling outside of general guarding, e.g. CIT, close protection, private investigators, etc.

C2. Prohibitions/Restrictions (2). If regulation contains a Speciality principle (2) and if not (0). The 'specialty principle' in private security means that one single legal entity, officially recognised as a private security company, is only allowed to carry out private security services and not auxiliary or additional services.

C3. In-house security personnel (4). If in-house security personnel, i.e. privately managed staff providing security services, is included in regulation (2) and if not (0).

Licensing consists of the following seven questions (L1-7):

L1. Licensing firms (8). If regulation contains comprehensive criteria (8), partial (4) and none (0). Criteria included but where not limited to consideration of; background checks, criminal records, financial viability, fees, age restrictions, minimum educational level, language proficiency, etc.

L2. Licensing operatives (8). If regulation contains comprehensive criteria (8), partial (4) and none (0). Criteria included but where not limited to consideration of; physical and psychological evaluations, criminal records, training certificates, fees, age restrictions, minimum educational level, language proficiency, etc. 
L3. Types of licenses (4). Different licenses may be issued for different roles and if such differences reflect a comprehensive licensing spectra (4), if partial (2) and if not (0). Licenses included but where not limited to; aviation/ airport security, CCTV related, close protection, CIT, maritime security, etc.

L4. License card (4). If a license card meeting the official EU standard for ID cards is issued (4) and if not (0).

L5. Compulsory codes of conduct (2). If existing (2) and if not (0). Note that this is one of the questions where compliance and adherence is highly relevant but as stated before was not considered.

L6. Special weapons and equipment (2). This question refers to the regulation of allowing guards to be armed with firearms. If it is regulated and consequently allowed or disallowed (2) and if unregulated (0).

L7. Working conditions (2). In legislation that affects the PSI, i.e. not necessarily specific for the PSI, are there sector specific binding agreements for working conditions? If yes (2) and if no (0).

The second main division is societal foundation consisting of the sub-divisions professional associations (4), enforcement (8) and training (30).

Professional associations is the only one-question sub-division consisting of only (A1).

A1. Professional associations (4). If there are professional associations assumed to promote higher, better and more effective standards than the statutory minimum, then (4), if not (0).

Enforcement consist of the following two questions (E1-2):

E1. Complaints procedure (4). If regulation provides specific provisions for making, managing and follow-up of complaints against private security individuals and/or entities then (4) if not (0).

E2. Sanctions for transgressions (4). This question refers to the possibility for the regulator to administer sanctions upon the security industry or individuals by criminal law (2), if also by administrative law (4) and if not at all (0).

Training consists of the following six questions (T1-6):

T1. Licensing of trainers (4). Is a license required to provide training of security personnel? If yes (4), and if not (0).

T2. Mandatory training (14). This question weighed mandatory training stipulated by the regulation. The range of hours, whose maximum value is justified in the article, provide the following range of points; 0 hours $=(0), 1$ to 19 hours $=(2), 20$ to 39 hours $=(4), 40$ to 59 hours $=(6), 60$ to 79 hours $=(8), 80$ to 99 hours $=(10), 100$ to 120 hours $=$ (12), and $121+$ hours $=(14)$.

T3. Exam (2). Upon successfully completing the basic training is there a theoretical and/or practical pass/fail exam after which private security guards are issued with a certificate of competence (2), and if not (0).

T4. Refresher training (4). Does mandatory refresher or follow-up training exist? If yes (4) if not (0).

T5. Specialist training (4). If mandatory specialist training is required for security roles other than general guarding then (4) and if not (0).

T6. Management/Supervisor training (4). If mandatory training is required for management and $/ \mathrm{r}$ supervisory roles of private security then (4) if not (0).

With simplified questions and several qualitative criteria judged subjectively the picture is not perfect but illustrates both the inter-question balance as well as their individual relevance.

\section{Disclosure statement}

No potential conflict of interest was reported by the authors.

\section{References}

Association of Police and Crime Commissioners, 2013. Police strength in England and Wales at March 2013. London: Association of Police and Crime Commissioners.

Berglund, T., n.d. The security industry in Europe - how to act and react towards Europe. Unpublished paper presented to the confederation of European security services.

Button, M., 2007a. Assessing the regulation of private security across Europe. European journal of criminology, 4, $109-128$.

Button, M., 2007b. Security officers and policing. Aldershot: Ashgate.

Button, M., 2008. Doing security: critical reflections and an agenda for change. Basingstoke: Palgrave.

Button, M., 2011. The private security industry act 2001 and the security management gap in the United Kingdom. Security journal, 24, 118-132. 
Button, M., 2012. Optimising security through effective regulation: lessons from around the globe. In: T. Prenzler, ed. Policing and security in practice. Basingstoke: Palgrave, 204-220.

Button, M. and George, B., 2006. Regulation of security: new models for analysis. In: M. Gill, ed. Handbook of security. London: Palgrave, 563-585.

Button, M. and Park, H., 2009. Security officers and the policing of private space in South Korea: profile, powers and occupational hazards. Policing and society, 19, 247-262.

Cihan, A., 2013. The private security industry in Turkey: officer characteristics and their perception of training sufficiency. Security journal. doi:10.1057/sj.2013.4.

CoESS, 1998. Case C-114/97. Available from: http://www.coess.eu/?CategorylD=325 [Accessed 10 October 2015].

CoESS, 2004. Annual Report 2004. Available from: http://www.coess.org/documents/annual_report_2004.pdf [Accessed 10 October 2015].

CoESS, 2011. Private security services in Europe. Brussels: COESS.

CoESS/UNI-Europa, 2004. Panoramic overview of private security industry in the 25 member states of the European Union. Available from: http://www.coess.org/pdf/panorama1pdf [Accessed 10 October 2015].

COM, 2012. 746. (2012). EU regulatory fitness. Strasbourg: European Commission.

Crawford, A. and Lister, S., 2004. The extended policing family. York: Joseph Rowntree Foundation.

Cunningham, W.C., Strauchs, J.J., and Van Meter, C.W., 1990. Private security trends 1970-2000. Hallcrest report II. Stoneham, MA: Butterworth-Heinemann.

Davis, M., 1998. City of Quartz: excavating the future in Los Angeles. London: Pimlico.

De Waard, J., 1993. The private security sector in fifteen European countries: size, rules and legislation. Security journal, 4 (2), 58-62.

De Waard, J., 1999. The private security industry in international perspective. European journal of criminal policy and research, 7 (2), 143-174.

De Waard, J. and Van De Hoek, J., 1991. Private security size and legislation in the Netherlands and Europe. The Hague: Dutch Ministry of Justice.

ECORYS, 2011. Security regulation, conformity assessment \& certification (vol. final report - volume l: main eport). Brussels: European Commission, DG Enterprise \& Industry.

EPC, 2013. The Stockholm programme: what's next? Paper presented at the Informal meeting of Justice and Home Affairs Ministers, Vilnius.

European Private Security Services Education and Training, 1999. European vocational training manual for basic guarding. Available from: http://www.eesc.europa.eu/resources/docs/138-private-act.pdf [Accessed 24 February 2015].

Eurostat, 2014. Police officers. Available from: http://appsso.eurostat.ec.europa.eu/nui/show.do?dataset=crim_plce\&lang= en\# [Accessed 12 January 2015].

Falkner, G., Hartlapp, M., and Treib, O. 2007. Worlds of compliance: why leading approaches to European Union implementation are only 'sometimes-true theories'. European journal of political research, 46 (3), 395-416.

Gimenez-Salinas, A., 2004. New approaches regarding private/public security. Policing and society, 14, $158-174$.

Glaser, B. G. and Strauss, A. L. 1967. The discovery of grounded theory: strategies for qualitative research. Chicago: Aldine Pub. Co.

Goold, B., Loader, I., and Thulma, A., 2010. Consuming security? Tools for a sociology of security consumption. Theoretical criminology, 14, 3-30.

Gross, E., 2013. Assessing the EU's approach to Security Sector Reform (SSR). Brussels: DG External Policies of the Union.

Hainmuller, J. and Lemnitzer, J.M., 2003. Why do Europeans fly safer? The politics of airport security in Europe and the US. Terrorism and political violence, 15, 1-36.

Hakala, J. 2008. Why regulate manned private security? Available from: http://www.coess.eu/_Uploads/dbsAttachedFiles/ Why_regulate_manned_private_security.pdf [Accessed 25 January 2015].

Hemmens, C., et al., 2001. Watching the watchmen: state regulation of private security 1982-1998. Security journal, 14, 1728.

Hough, M., Jackson, J., and Bradford, B., 2012. Trust in justice and the legitimacy of legal authorities: topline findings from a European comparative study. In: S. Body-Gendrot, H. Mike, K. Kerezsi, R. Levy, and S. Snacken, eds. The Routledge handbook of european criminology. Routledge international handbooks. Abingdon, UK: Routledge, 243-265. ISBN 9780415685849.

House of Commons Home Affairs Committee (HAC), 1995. The private security industry. Vol I and II. HC 17. London: HMSO. Johnston, L. and Shearing, C.D., 2003. Governing security. London: Routledge.

Jones, T. and Newburn, T., 1998. Private security and public policing. Oxford: Clarendon Press.

Jones, T. and Newburn, T., eds., 2006. Plural policing. Abingdon: Routledge.

Labayle, H. and Bruycker, P.D., 2013. Towards the negotiation and adoption of the Stockholm programme's successor. Brussels: European Parliament.

Lacey, N., 2008. The prisoners' dilemma: political economy and punishment in contemporary democracies. Cambridge, UK: Cambridge University Press.

Loader, I., 1997. Thinking normatively about private security. Journal of law and society, 24 (3), 377-94.

Milne, B. and Bull, R. 1999. Investigative interviewing: psychology and practice. Chichester: Wiley. 
Ocqueteau, F., 2006. France. In: T. Jones and T. Newburn, eds. Plural policing. Abingdon: Routledge, 55-76.

Pakes, F., 2004. Comparative criminal justice. 3rd ed. Abingdon: Routledge.

Palmer, R. and Button, M., 2011. Civilian private security services: their role, oversight and contribution to crime prevention and community safety. Expert group on civilian private security services, Oct 12-14. Vienna: United Nations Office on Drugs and Crime.

Perrons, D. and Plomien, A., 2010. Why socio-economic inequalities increase? Facts and policy responses in Europe. Luxembourg: European Commission.

Pidgeon, N. and Henwood, K., 1997. Using grounded theory in psychological research. In: N. Hayes, ed. Doing qualitative analysis in psychology. Hove: Psychology Press, 245-273.

Prenzler, T. and Sarre, R., 1999. A survey of security legislation and regulatory strategies in Australia. Security journal, 12, 717.

Prenzler, T. and Sarre, R., 2008. Developing a risk profile and model regulatory system for the security industry. Security journal, 21, 264-277.

Prenzler, T., Baxter, T., and Draper, R., 1998. Special legislation for the security industry: a case study. International journal of risk, security and crime prevention, 3, 21-33.

Rigakos, G.S., 2002. The new parapolice. Toronto: University of Toronto Press.

Santonen, T. and Passonen, J., 2014. Evaluating the adequacy of private security regulation in Finland. Security journal. doi:10.1057/sj.2014.33.

Sarre, R. and Prenzler, T., 2011. Private security and public interest: exploring private security trends and directions for reform in the new era of plural policing. Sydney: ARC Report.

Security Industry Authority, 2014. The SIA in statistics: January 2014. Available from: http://www.sia.homeoffice.gov.uk/ Pages/about-news.aspx?newsID=473\&ArtTypeID=13 [Accessed 23 March 2014].

Shearing, C.D. and Stenning, P.C., 1982. Private security and private justice. Montreal: The Institute on Public Policy.

Small Arms Survey, 2011. A booming business private security and small arms. Geneva: Small Arms Survey.

Smith, M.J. and White, A. 2014. The Paradox of security regulation: public protection versus normative legitimation. Policy and politics, 42 (3), 421-437. doi:10.1332/030557312X655495.

Stenning, P.C., 1989. Private police and public police: toward a redefinition of the police role. In: D.J. Loree, ed. Future issues in policing symposium proceedings. Ottawa: Canadian Police College, 169-192.

United Nations Office on Drugs and Crime, 2014. State regulation concerning the civilian private security services and their contribution to crime prevention and community safety. Vienna: UNODC.

Van Steden, R., 2007. Privatizing policing. Amsterdam: BJU.

Van Steden, R. and Sarre, R., 2007. The growth of private security: trends in the European Union. Security journal, 20, 222235.

Wakefield, A., 2003. Selling security - the private policing of public space. Cullompton: Willan.

Weber, T., 2002. A comparative overview of legislation governing the private security industry in the European Union. Available from: http://www.coess.org/pdf/final-study.PDF [Accessed 27 September 2014].

White, A., 2010. The politics of private security. Basingstoke: Palgrave.

Wilkinson, R. and Pickett, K., 2009. The spirit level. Why more equal societies almost always do better. London: Allen Lane. 